\title{
Implications of Three Biofuel Crops for Beneficial Arthropods in Agricultural Landscapes
}

\author{
Mary A. Gardiner • Julianna K. Tuell • Rufus Isaacs • \\ Jason Gibbs • John S. Ascher • Douglas A. Landis
}

Published online: 23 January 2010

(C) Springer Science+Business Media, LLC. 2010

\begin{abstract}
Production of biofuel feedstocks in agricultural landscapes will result in land use changes that may have major implications for arthropod-mediated ecosystem services such as pollination and pest suppression. By comparing the abundance and diversity of insect pollinators and generalist natural enemies in three model biofuel crops: corn, switchgrass, and mixed prairie, we tested the hypothesis that biofuel crops comprised of more diverse plant communities would support increased levels of beneficial insects. These three
\end{abstract}

Electronic supplementary material The online version of this article (doi:10.1007/s12155-009-9065-7) contains supplementary material, which is available to authorized users.

M. A. Gardiner · D. A. Landis $(\bowtie)$

Department of Entomology and DOE Great Lakes Bioenergy

Research Center, Michigan State University,

Center for Integrated Plant Systems,

East Lansing, MI 48824, USA

e-mail: landisd@msu.edu

J. K. Tuell $\cdot$ R. Isaacs

Department of Entomology and DOE Great Lakes Bioenergy

Research Center, Michigan State University,

202 Center for Integrated Plant Systems,

East Lansing, MI 48824, USA

J. Gibbs

York University,

4700 Keele Street,

Toronto, ON M3J 1P3, Canada

J. S. Ascher

Division of Invertebrate Zoology,

American Museum of Natural History,

New York, NY 10024-5192, USA

Present Address:

M. A. Gardiner

Department of Entomology, The Ohio State University,

Wooster, OH 44691, USA biofuel crops contained a diverse bee community comprised of 75 species. Overall, bees were three to four times more abundant in switchgrass and prairie than in corn, with members of the sweat bee (Halictidae) and small carpenter bee (Ceratina spp.) groups the most abundant. Switchgrass and prairie had significantly greater bee species richness than corn during the July sampling period. The natural enemy community at these sites was dominated by lady beetles (Coccinellidae), long-legged flies (Dolichopodidae), and hover flies (Syrphidae) which varied in their response to crop type. Coccinellids were generally most abundant in prairie and switchgrass, with the exception of the pollen feeding Coleomegilla maculata that was most abundant in corn. Several rare or declining coccinellid species were detected in prairie and switchgrass sites. Dolichopodidae were more abundant in prairie and switchgrass while Syrphidae showed no significant response to crop type. Our results indicate that beneficial insects generally responded positively to the increased vegetational diversity of prairie and switchgrass sites; however, when managed as a dedicated biofuel crop, plant and arthropod diversity in switchgrass may decrease. Our findings support the hypothesis that vegetationally diverse biofuel crops support higher abundance and diversity of beneficial insects. Future policy regarding the production of biofuel feedstocks should consider the ecosystem services that different biofuel crops may support in agricultural landscapes.

Keywords Agricultural landscapes · Bees · Biodiversity · Ecosystem services $\cdot$ Natural enemies

\section{Introduction}

Biofuel production could dramatically alter our nation's agricultural landscapes, making it imperative that biofuel 
crops are chosen that are both productive and sustainable. In the USA, an annual target of 35 billion gallons of ethanol by 2022 has stimulated intense interest in methods for production of liquid fuels from plant biomass [38, 47]. Large-scale production and harvest of any field-grown biofuel feedstock is likely to have profound implications for land use and biodiversity [5]. In particular, there is growing awareness of the potential ecological and societal ramifications of increased plantings of crop monocultures for fuel $[24,45]$. In the US, current technology has focused on producing ethanol from corn grain (Zea mays L.) with implications for commodity prices [50], crop rotations [27], and potential for indirect shifts in land use resulting in greater carbon emissions globally [39]. Alternatively, production of liquid fuels from nonfood plant biomass (lignocelluloses) has the potential to avoid many of the problems of corn ethanol [34].

Technological innovations may soon make cellulosic biofuels a viable alternative to corn ethanol, allowing production goals to be met while supporting biodiversity and ecosystem services (sensu [8]). Two potential future cellulosic biofuel crops are switchgrass, Panicum virgatum L., and mixed prairie which is the historical vegetation of the corn-dominated regions of the Midwest. Switchgrass is a warm-season grass native to North America that can grow on land too poor for food production [23] and which has shown high biomass productivity in US field trials [37]. An alternative biofuel crop that has been proposed for the Midwestern US is the planting of perennial prairies, i.e., mixtures of native grass and forbs [44], which are anticipated to have energetic benefits over annual crops and potentially reduce contributions to greenhouse gases ([15, 44]; but see [35]).

If grown widely, future cellulosic biofuel crops may fundamentally change the structure and function of agricultural landscapes. While such landscapes are currently primarily managed to maximize the provisioning service of crop production, they also harbor biodiversity that supports a wide array of other ecosystem services [11]. For example, beneficial arthropods such as bees provide essential transfer of pollen between flowers, and generalist predators support crop production by suppressing insect pest populations. The value of such arthropod-mediated ecosystem services [17] has been estimated to be worth $\$ 57 \mathrm{~B}$ per year across the crops grown in the US [21]. Of this total, pollination services are estimated to comprise $\$ 3.1 \mathrm{~B}$ and biological pest control services another \$4.5B. Land use changes associated with biofuel feedstock production may have unintended consequences on these ecosystem services. Landis et al. [19] found that the pest suppression service of soybean aphid control by predatory insects is worth over \$200 million/year annually in four Midwestern states, but this was reduced by $24 \%$ when more corn was grown in the landscape. Similarly, landscape composition is a major determinant of the ability of bees to nest and locate suitable nectar and pollen resources, with greater bee abundance and reproduction in regions that have diverse flowering plant communities and a range of nesting substrates [28, 29, 32, 51].

Both the relative habitat stability (annual versus perennial) and floristic diversity of biofuel crops are anticipated to influence arthropod community structure and function [20]. Prior studies of arthropod communities in herbaceous biofuel crops include comparison of ground-dwelling and arboreal arthropods in winter wheat versus miscanthus (Miscanthus $x$ giganteus) and reed canary grass (Phalaris arundinacea L.) in England [3, 40] and carabid beetles in corn and switchgrass in the southeastern USA [48]. Perennial crops such as switchgrass and mixed prairie are anticipated to provide greater habitat stability than annual crops, and this is expected to increase the diversity and abundance of beneficial insects in these fields [1]. As a dedicated biofuel crop, switchgrass stands are planted as monocultures, and established stands have few weeds [25]. Thus, while providing habitat stability, biofuel switchgrass stands are anticipated to have relatively low plant diversity. In contrast, perennial prairie mixtures could provide both stable and floristically diverse habitat for beneficial insects and are expected to support the most abundant and diverse insect populations.

As part of the Great Lakes Bioenergy Research Center (GLBRC), we are studying the biodiversity implications of different biofuel crop production systems. Overall, the GLBRC is investigating a wide array of potential biofuel feedstock plants ranging from annual monocultures to perennial polycultures. Our aim in this research is to determine whether there are biofuel scenarios that can provide adequate feedstock supplies while supporting the biodiversity on which agricultural landscapes depend. For this study, we selected three potential biofuel feedstock crops (corn, switchgrass, and mixed prairie) that represent different points on this continuum. We tested the hypothesis that the abundance and diversity of both native bees and generalist natural enemies would be lowest in corn, intermediate in switchgrass, and greatest in mixed prairie.

\section{Methods}

Research Sites Ten replicate sites of each of three biofuel crop treatments, corn, switchgrass, and mixed prairie, were selected from preexisting fields throughout southern Michigan (Fig. 1, Table S1). The absence of current markets for cellulosic biomass means that these fields were not actively managed for that purpose. All corn fields were managed for corn grain production using conventional agronomic prac- 


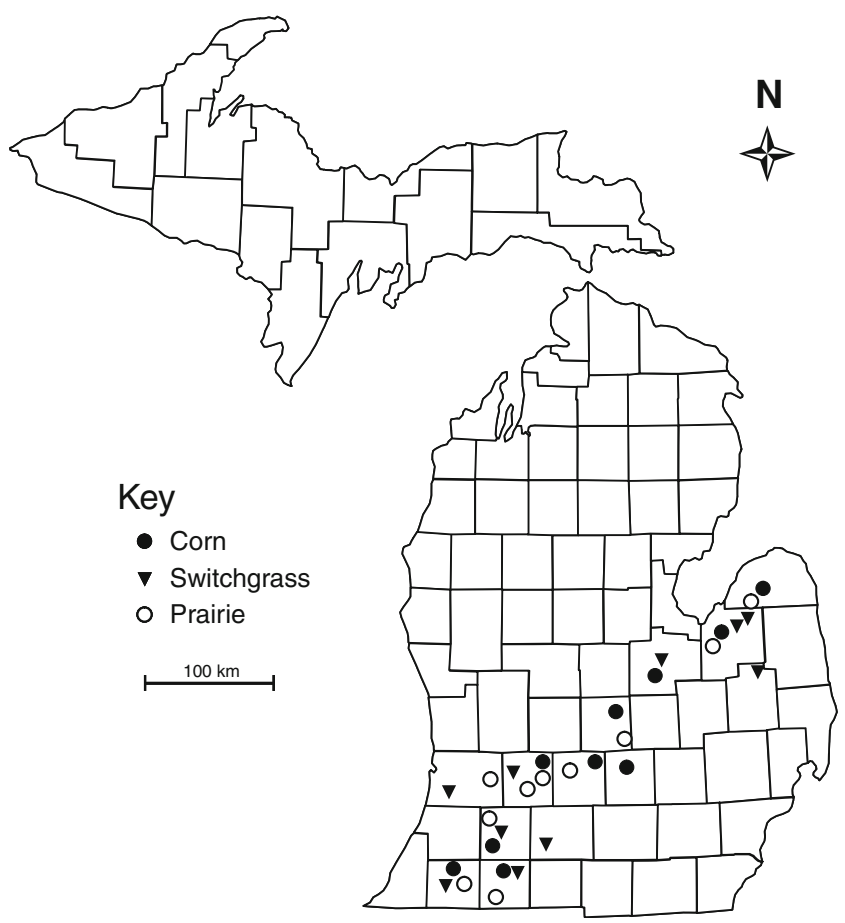

Fig. 1 Map of Michigan, USA, illustrating the location of the 30 sampling sites consisting of three biofuel crop treatments: corn $(n=$ $10)$, switchgrass $(n=10)$, and prairie $(n=10)$ which were sampled for bees and insect predators in 2008

tices, while switchgrass and mixed prairie were primarily managed for wildlife habitat or as native community restorations. Within each treatment, sites were selected across a range of landscapes that varied in structural heterogeneity and the amount of noncrop habitat in the surrounding landscape. Each site was a minimum of 2 ha in size and a minimum distance of $5 \mathrm{~km}$ from other sites. Within each site, four sampling points were established throughout the field with each point a minimum of $15 \mathrm{~m}$ from any edge. The insect sampling protocols described below were conducted at each sampling point.

Plant Diversity Sampling Within the 20 prairie and switchgrass sites, plant diversity was estimated using a modified Whittaker sampling procedure [41] in which all plant species were identified within a $100-\mathrm{m}^{2}$ area around each sampling point. Similar plant diversity sampling was not conducted in corn; however, within all crops, the number and identity of all blooming dicots was determined during bee sampling (mid-June, mid-July, and mid-August) within a $100-\mathrm{m}^{2}$ area around each sampling point.

Bee Sampling During three sampling periods, 16-20 June, 14-18 July, and 11-15 August 2008, bee abundance was measured using pan traps consisting of $3.25 \mathrm{oz}$ white soufflé cups (Solo Cup Co., Urbana, IL, USA) filled with a $2 \%$ aqueous solution of Dawn Co. dish soap to act as a surfactant. One third of the traps were left white, and the remainder were painted fluorescent yellow or fluorescent blue using the standard methods described by Droege [10]. Four sets of the three colors, a total of 12 pan traps, were deployed for a period of $48 \mathrm{~h}$ at each site. One trap of each color was placed at each sampling point. Traps were placed on the ground and separated from each other by a distance of $3 \mathrm{~m}$. The contents of all the pan traps for a single site within a single sample period were strained together and placed in $95 \%$ ethanol for preservation until they could be washed, dried, and pinned for identification.

Natural Enemy Sampling The activity of flying generalist predators was measured using yellow sticky card traps [12, 13]. At each sampling point, a single unbaited yellow sticky card (PHEROCON AM, Great Lakes IPM, Vestaburg, MI, USA) was attached to a step-in fence post at a height of $1 \mathrm{~m}$. Sticky cards were replaced weekly from early June through mid-August and returned to the laboratory for insect identification.

Insect Identification The online key to Bees of Eastern North America at www.discoverlife.org was used to identify most bees to species, except for members of three genera: Andrena, Hylaeus, and Lasioglossum (Dialictus) which were identified by specialists. A few specimens were unable to be determined to species and are listed by genus only. These specimens were included in the abundance data, but not in the species count data. All Coccinellidae (lady beetles) were identified to species directly from yellow sticky card traps. Other flying predators indentified to family included: Syrphidae (hover flies), Nabidae (damsel bugs), Chrysopidae (lacewings), Hemerobiidae (brown lacewings), and partially predatory groups including the Dolichopodidae (long-legged flies), and Empididae (dance flies). Voucher specimens for all groups were deposited in the Albert J. Cook Arthropod Research Collection at Michigan State University.

Insect Diversity A Simpson's Diversity Index $(D)$ was used to estimate bee and natural enemy diversity by site: $D=$ $1 / \sum\left(p_{i}\right)^{2}$ where $p_{i}=$ proportion of pollinator or natural enemy community in the $i$ th species category ( $D$ increases as diversity increases) [42].

Statistical Methods Bee abundance and species richness were analyzed using a mixed-effects analysis of variance model, with treatment as the fixed effect and sampling period as the random effect. Natural enemy abundance data were analyzed using a repeated-measures mixed-effects analysis of variance (ANOVA) model with treatment (corn, switchgrass, and prairie) as a fixed effect, sampling point within site as a random effect, and week the repeated factor. 
Lady beetle diversity $(D)$ was analyzed using an ANOVA model with treatment (corn, switchgrass, and prairie) as a fixed effect based on season-long catches at the site level.

Akaike's Information Criterion, adjusted for a small sample size $\left(\mathrm{AIC}_{\mathrm{c}}\right)$, was used as a model selection procedure to examine four models as potential predictors of bee abundance, bee species richness, abundance of ladybeetles, abundance of native lady beetles, abundance of exotic lady beetles, and lady beetle species richness within prairie and switchgrass sites. The four models examined were intercept only, area (area of each field site in $\mathrm{Ha}$ ), plant richness (mean plant diversity measured at a distance of $100 \mathrm{~m}^{2}$ surrounding each sampling point within each field site), and bloom (mean number of flowering plants present during bee sampling periods, measured at a distance of $100 \mathrm{~m}^{2}$ surrounding each sampling point). For each response variable, we present the model with the minimum $\mathrm{AIC}_{\mathrm{c}}$ value, i.e., with the best support for the data, and any competing models with an $\mathrm{AIC}_{\mathrm{c}}$ difference of less than two $[53,54]$. For each model, we present the maximum loglikelihood estimate, the Akaike weights which estimate the relative likelihood of a given model against all other models, and $\mathrm{AIC}_{\mathrm{c}}$ differences $\left(\Delta_{i}\right)$. We calculated the model $r^{2}$ for the minimum $\mathrm{AIC}_{\mathrm{c}}$ model and competing models to evaluate how well the models explained the variation in the data. The best overall model was defined as the model with the lowest $\mathrm{AIC}_{\mathrm{c}}$ score. The $\mathrm{AIC}_{\mathrm{c}}$ analysis was completed only for prairie and switchgrass sites because corn fields were almost completely dominated by Z. mays and had little variability in plant diversity. Models with multiple variables were not compared due to the low number of replicates per treatment $(n=10)$. All response variables were $\log (x+1)$-transformed prior to analysis. SAS version 9.2 was used to conduct ANOVA model analysis, and $\mathrm{R}$ version 2.8.1 was used for simple linear regression analyses (SAS $[31,36])$. To determine whether community composition differed among the biofuel crop types for the bee species and coccinellid beetles captured, separate multiple-response permutation procedure (MRPP, "vegan" package in $\mathrm{R} 2.8 .1$ ) analyses were conducted using the Bray-Curtis distance metric and 1,000 iterations.

\section{Results}

Plant Composition and Flowering A total of 143 and 127 plant species were collected from switchgrass and prairie sites, respectively. These included native grasses, sedges, and forbs as well as several common weedy and invasive species (Table S2). Switchgrass fields contained a mean of 27 species (range 13-38) while prairie averaged 34.6 (range 24-49). A total of 33,44, and one species were in bloom during bee collections in switchgrass, prairie, and corn sites, respectively (Table S2).

Bee Community Composition A total of 1,779 bees of 75 species (Table 1) were captured across the 30 sites. A similar number of species was found in each biofuel type, but there were three to four times more bees captured in the switchgrass and prairie (885 and 681 individuals, respectively) compared with the corn (213). Some of the most abundant bees were Ceratina species trapped in high numbers in the switchgrass and prairie sites but absent from corn. Many of the halictid bees such as Agapostemon virescens, Augochlorella aurata, and Halictus confusus were present in corn but much more abundant in the other biofuel types (Table 1). A few other halictid bees such as Lasioglossum atlanticum and Lasioglossum leucozonium had similar but relatively lower abundance across biofuel types.

The mean number of bees was greatest in switchgrass through the summer, but there was no significant difference between the switchgrass and prairie sites (Fig. 2). In June and July, there was a significant difference among all biofuel types in abundance of bees captured (June: $F_{2,27}=$ 4.15, $P=0.03$; July: $F_{2,27}=4.77, P=0.02$ ) with significantly more bees in the switchgrass sites than in the corn. There was no significant difference among biofuel crops in August $\left(F_{2,27}=0.62, P=0.55\right)$. Captures of bees declined through the summer in the prairie and switchgrass sites, whereas captures in the corn declined initially and leveled off (Fig. 2). Species richness also declined through the summer in our samples, with a significant difference among biofuel types only in July $\left(F_{2,27}=9.90, P=0.0006\right)$ when the bee community was richer in switchgrass and prairie than in corn (Fig. 2).

While many of the bee species were found in more than one biofuel crop type, overall bee community composition across the season was significantly different (MRPP analysis) between corn and switchgrass $(P<0.001)$ and between corn and prairie $(P<0.001)$, but not between switchgrass and prairie $(P=0.22)$. Figure $\mathrm{S} 1$ provides an illustration of these differences at the generic level. Corn and switchgrass were dominated by Lasioglossum spp., while switchgrass and prairie had higher proportions of Ceratina spp.

Lady Beetle Diversity and Abundance Four species of exotic and eight species of native lady beetles were collected from the biofuel crop treatments (Table 2). Differences in coccinellid abundance among the biofuel treatments varied across the season, as indicated by a significant interaction between week and treatment $\left(F_{16,942}=5.81, P<0.0001\right)$. Corn fields had a significantly higher abundance of total coccinellids compared with prairie and switchgrass begin- 
Table 1 Bee species collected in southern Michigan from ten sites in each of three biofuel crops using pan traps during 2008. Abundance values are summed across three sample dates

\begin{tabular}{|c|c|c|c|c|}
\hline Family and species & Corn & Switchgrass & Prairie & Total \\
\hline \multicolumn{5}{|l|}{ Andrenidae } \\
\hline Andrena carlini Cockerell & - & - & 1 & 1 \\
\hline Andrena commoda Smith & 15 & 11 & 8 & 34 \\
\hline Andrena crataegi Robertson & 2 & - & - & 2 \\
\hline Andrena cressonii Robertson & 2 & 8 & 9 & 19 \\
\hline Andrena geranii Robertson & - & 1 & - & 1 \\
\hline Andrena nasonii Robertson & 2 & 3 & 8 & 13 \\
\hline Andrena perplexa Smith & 3 & 2 & & 5 \\
\hline Andrena wilkella (Kirby) & 1 & - & 2 & 3 \\
\hline Andrena spp. & - & - & 3 & 3 \\
\hline Calliopsis andreniformis Smith & - & 2 & - & 2 \\
\hline \multicolumn{5}{|l|}{ Apidae } \\
\hline Anthophora spp. & 1 & 1 & - & 2 \\
\hline Apis mellifera $\mathrm{L}$. & - & 4 & 5 & 9 \\
\hline Bombus impatiens Cresson & 1 & - & 3 & 4 \\
\hline Bombus vagans Smith & - & 1 & - & 1 \\
\hline Ceratina calcarata (males) Robertson & - & 2 & - & 2 \\
\hline Ceratina calcarata/dupla (females) Robertson/Say ${ }^{\mathrm{a}}$ & 1 & 123 & 177 & 301 \\
\hline Ceratina dupla (males) Say & - & 32 & 15 & 47 \\
\hline Ceratina strenua Smith & - & 24 & 24 & 48 \\
\hline Eucera hamata (Bradley) & 10 & 6 & 2 & 18 \\
\hline Melissodes bimaculata (Lepeletier) & 22 & 4 & 4 & 30 \\
\hline Melissodes desponsa Smith & - & 1 & 2 & 3 \\
\hline Melissodes druriella (Kirby) & - & - & 1 & 1 \\
\hline Melissodes nivea Robertson & - & 1 & - & 1 \\
\hline Melissodes trinodis Robertson & 1 & - & - & 1 \\
\hline Nomada spp. & 1 & 5 & 5 & 11 \\
\hline Peponapis pruinosa (Say) & - & 1 & 1 & 2 \\
\hline \multicolumn{5}{|l|}{ Colletidae } \\
\hline Hylaeus affinis (Smith) & - & 4 & 14 & 18 \\
\hline Hylaeus affinis/modestus (Smith)/Say ${ }^{\mathrm{b}}$ & - & 5 & 36 & 41 \\
\hline Hylaeus spp. & 1 & 8 & 7 & 16 \\
\hline \multicolumn{5}{|l|}{ Halictidae } \\
\hline Agapostemon sericeus (Förster) & 4 & 2 & - & 6 \\
\hline Agapostemon splendens (Lepeletier) & - & 3 & - & 3 \\
\hline Agapostemon texanus Cresson & 3 & 10 & 1 & 14 \\
\hline Agapostemon virescens (Fabricius) & 17 & 54 & 44 & 115 \\
\hline Augochlorella aurata (Smith) & 6 & 50 & 69 & 125 \\
\hline Dufourea novaeangliae (Robertson) & - & - & 1 & 1 \\
\hline Halictus confusus Smith & 1 & 23 & 31 & 55 \\
\hline Halictus ligatus Say & - & 6 & 15 & 21 \\
\hline Halictus parallelus Say & 3 & 1 & - & 4 \\
\hline Halictus rubicundus (Christ) & - & - & 1 & 1 \\
\hline Lasioglossum admirandum (Sandhouse) & 10 & 120 & 13 & 143 \\
\hline Lasioglossum albipenne (Robertson) & 5 & 3 & 8 & 16 \\
\hline Lasioglossum anomalum (Robertson) & 4 & 11 & 11 & 26 \\
\hline Lasioglossum atlanticum (Mitchell) & 40 & 23 & 20 & 83 \\
\hline Lasioglossum cinctipes (Provancher) & 1 & - & - & 1 \\
\hline
\end{tabular}


Table 1 (continued)

\begin{tabular}{|c|c|c|c|c|}
\hline Family and species & Corn & Switchgrass & Prairie & Total \\
\hline Lasioglossum coeruleum (Robertson) & 1 & - & - & 1 \\
\hline Lasioglossum coriaceum (Smith) & 4 & 21 & 13 & 38 \\
\hline Lasioglossum divergens (Lovell) & 1 & - & - & 1 \\
\hline Lasioglossum ellisiae (Sandhouse) & 1 & - & - & 1 \\
\hline Lasioglossum hartii (Robertson) & 1 & - & - & 1 \\
\hline Lasioglossum leucozonium (Schrank) & 17 & 22 & 10 & 49 \\
\hline Lasioglossum lineatulum (Crawford) & - & - & 1 & 1 \\
\hline Lasioglossum nymphaearum (Robertson) & - & 16 & 2 & 18 \\
\hline Lasioglossum paradmirandum (Knerer \& Atwood) & 2 & 1 & 2 & 5 \\
\hline Lasioglossum paraforbesii McGinley & - & 1 & - & 1 \\
\hline Lasioglossum pectorale (Smith) & 9 & 48 & 28 & 85 \\
\hline Lasioglossum perpunctatum (Ellis) & - & 3 & - & 3 \\
\hline Lasioglossum pictum (Crawford) & 1 & - & - & 1 \\
\hline Lasioglossum pilosum (Smith) & 1 & 68 & 22 & 91 \\
\hline Lasioglossum planatum (Lovell) & - & 2 & - & 2 \\
\hline Lasioglossum platyparium (Robertson) & 2 & - & - & 2 \\
\hline Lasioglossum pruinosum (Robertson) & 1 & 1 & - & 2 \\
\hline Lasioglossum tegulare (Robertson) & 8 & - & - & 8 \\
\hline Lasioglossum versatum (Robertson) & - & 32 & 29 & 61 \\
\hline Lasioglossum vierecki (Crawford) & - & 20 & - & 20 \\
\hline Lasioglossum viridatum (Lovell) & 1 & 9 & 8 & 18 \\
\hline Lasioglossum zonulum (Smith) & 3 & 20 & 6 & 29 \\
\hline Sphecodes spp. & 2 & 1 & 2 & 5 \\
\hline \multicolumn{5}{|l|}{ Megachilidae } \\
\hline Hoplitis pilosifrons (Cresson) & - & 49 & 8 & 57 \\
\hline Hoplitis pilosifrons or producta $(\text { Cresson })^{\mathrm{c}}$ & - & 1 & 2 & 3 \\
\hline Hoplitis producta (Cresson) & - & 1 & - & 1 \\
\hline Hoplitis spoliata (Provancher) & 1 & - & 1 & 2 \\
\hline Hoplitis truncata (Cresson) & - & 2 & 1 & 3 \\
\hline Megachile sp. Latreille & - & 2 & 1 & 3 \\
\hline Osmia distincta Cresson & - & 1 & - & 1 \\
\hline Osmia proxima Cresson & - & 1 & - & 1 \\
\hline Osmia pumila Cresson & - & 1 & - & 1 \\
\hline Osmia simillima Smith & - & - & 1 & 1 \\
\hline Stelis lateralis Cresson & - & 7 & 3 & 10 \\
\hline Total & 213 & 885 & 681 & 1,779 \\
\hline Number of species ${ }^{\mathrm{d}}$ & 42 & 55 & 46 & 75 \\
\hline
\end{tabular}

${ }^{a}$ Females of $C$. calarata and $C$. dupla are morphologically difficult to separate although improved identification criteria are now available [30]

${ }^{\mathrm{b}}$ Identification of female Hylaeus (Prosopis) is problematic based on morphology alone

${ }^{\mathrm{c}}$ The condition of these specimens made them indistinguishable

${ }^{\mathrm{d}}$ Total does not include those identified to genus only

ning the weeks of 14 and 21 July, respectively, and continuing throughout the rest of the sampling period (Fig. 3a). There were no significant differences in the mean number of Coccinellidae collected from prairie and switchgrass fields (Fig. 3a). The native coccinellid Coleomegilla maculata represented $80 \%$ of the total coccinellid commu- nity in corn and averaged $1.33 \pm 0.15$ per sticky trap across the season (Table 2). When the abundance of coccinellids was examined without $C$. maculata, differences among the treatments also varied by week (week $\times$ treatment interaction $\left.F_{16,942}=1.58, P=0.0667\right)$. Compared with corn fields, coccinellid abundance (without C. maculata) was signifi- 

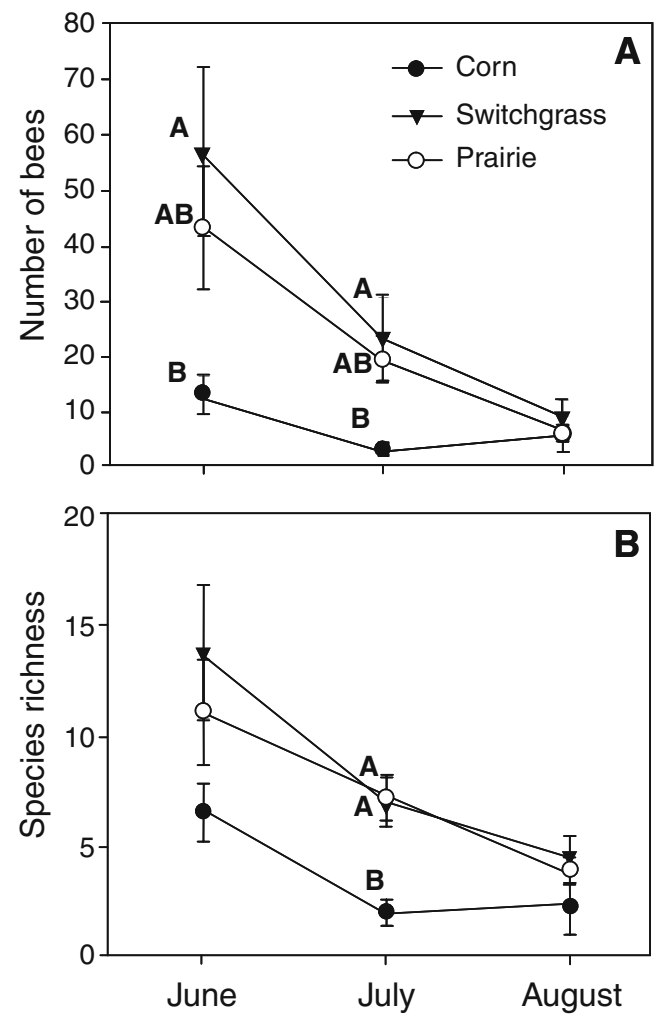

Fig. 2 Mean number of (a) bees trapped ( $\pm \mathrm{SE})$ and (b) bee species richness at corn, switchgrass, and prairie sites sampled during June, July, and August 2008. Letters indicate significant differences among treatments by month, measured using least squares means $(P<0.05)$. Unmarked months indicate no significant differences among the three treatments

cantly greater in switchgrass fields during the weeks of 7 July and 21 July and at sites with prairie during the weeks of 7 July and 28 July (Fig. 3b).

The composition of the coccinellid communities in prairie and switchgrass fields exhibited lower dominance and increased species richness compared with corn fields (Fig. S2). When we examined the range of Simpson's diversity $(D)$ values for these treatments, we found that the diversity of lady beetles was influenced by biofuel crop treatment $\left(F_{2,27}=6.36, P=0.0055\right)$. The diversity of coccinellids collected from switchgrass (LSmeans $P=0.0312$ ) and prairie (LSmeans $P=0.0072$ ) sites was greater than corn; however, there was no difference in the diversity of coccinellids among switchgrass and prairie sites (LSmeans $P=0.9071$; Fig. S2). Likewise, MRPP analysis revealed that the coccinellid community composition was significantly different across crop types $(P<0.001)$. The exotic Coccinella septempunctata was the most abundant species collected from both prairie and switchgrass. Brachyacantha ursina and Propylea quatuordecimpunctata were the second most abundant species collected from prairie and switchgrass sites, respectively (Table 2). Four coccinellid species, Hippodamia glacialis, Hyperaspis binotata, Hyperaspis undulata, and Psyllobora sp., were also found in prairie and/or switchgrass sites (Table 2, Fig. S2).

Predatory Fly Abundance Dolichopodidae were the most abundant natural enemy collected across all biofuel crop treatments (Table 2), reaching a mean abundance of 13.1 per sticky card in prairie sites during the week of August 11 (Fig. 3c). Differences in abundance among the treatments varied across time, leading to a significant interaction between week and treatment $\left(F_{16,942}=3.49, P<0.0001\right)$. Corn fields had significantly lower dolichopodid abundance compared with both prairie and switchgrass throughout most of the season (Fig. 3c). Abundance of this group in prairie and switchgrass differed only during the last 3 weeks of the study (28 July-11 August) when prairie had significantly higher catches. Syrphidae was the second most abundant family of predators collected from sticky traps in both prairie and switchgrass fields. In all treatments, syrphid abundance peaked in June then declined throughout the remainder of the season (Fig. 3d). There was a significant interaction between week and treatment $\left(F_{16}\right.$, $\left.{ }_{941}=2.51, P=0.0009\right)$ in syrphid abundance. The biofuel crop treatment with the greatest abundance of Syrphidae varied over time, with all treatments having significantly more individuals per sticky trap than at least one other treatment during at least 1 week. Catches of Empididae were relatively low across the three treatments (Table 2).

Damsel Bug and Lacewing Abundance Predatory Nabidae, Chrysopidae, and Hemerobiidae were found in all three biofuel crop treatments (Table 2). The abundance of Nabidae peaked in prairie in late June, reaching 0.4 per sticky card and in corn in late July reaching 0.25 per sticky card. The abundance of Nabidae in switchgrass remained low and relatively constant throughout the sampling period (Fig. 3e). Differences in nabid abundance among the treatments varied by week (week $\times$ treatment interaction $F_{16,941}=3.84, P=0.0001$ ), with prairie and corn having significantly more nabids present than the other treatments on 30 June and 21 July, respectively. There were no significant differences among biofuel crop treatments in terms of the abundance of Hemerobiidae or Chrysopidae.

Bee and Coccinellid Relationships with Field Variables In switchgrass, field area was the best fit model for each of the six arthropod variables examined, exhibiting the lowest $\mathrm{AIC}_{\mathrm{c}}$ values (Table 3). For coccinellid species richness, the plant richness model was a competing model (Table 3). No competing models were found for the other five response variables examined for this biofuel crop. Bee abundance, bee species richness, coccinellid abundance, coccinellid species richness, native coccinellid abundance, and exotic coccinellid abundance all exhibited positive correlations with the area of 
Table 2 Mean number $( \pm$ SEM $)$ of Dolichopodidae, Empididae, Syrphidae, Chrysopidae, Hemerobiidae, Nabidae, and Coccinellidae collected on yellow sticky traps sampled weekly from 16 June to 11 August 2008 in corn, prairie, and switchgrass fields across southern Michigan

\begin{tabular}{|c|c|c|c|c|}
\hline \multirow[t]{2}{*}{ Order } & \multirow[t]{2}{*}{ Family } & \multicolumn{3}{|l|}{ Mean \pm SEM } \\
\hline & & Corn & Switchgrass & Prairie \\
\hline \multirow[t]{16}{*}{ Coleoptera } & Coccinellidae (all) & $1.65 \pm 0.16$ & $0.55 \pm 0.06$ & $0.57 \pm 0.05$ \\
\hline & Coccinellidae without $C$. maculata & $0.33 \pm 0.04$ & $0.51 \pm 0.06$ & $0.54 \pm 0.05$ \\
\hline & Exotic Coccinellidae species & & & \\
\hline & Coccinella septempunctata & $0.04 \pm 0.01$ & $0.15 \pm 0.02$ & $0.21 \pm 0.03$ \\
\hline & Harmonia axyridis & $0.05 \pm 0.01$ & $0.03 \pm 0.01$ & $0.03 \pm 0.01$ \\
\hline & Hippodamia variegata & $0.01 \pm 0.004$ & $0.02 \pm 0.01$ & 0 \\
\hline & Propylea quatuordecimpunctata & $0.12 \pm 0.03$ & $0.13 \pm 0.02$ & $0.07 \pm 0.02$ \\
\hline & Native Coccinellidae species & & & \\
\hline & Brachyacantha ursina & 0 & $0.08 \pm 0.02$ & $0.11 \pm 0.02$ \\
\hline & Coleomegilla maculata & $1.33 \pm 0.15$ & $0.04 \pm 0.01$ & $0.02 \pm 0.01$ \\
\hline & Cycloneda munda & $0.10 \pm 0.03$ & $0.08 \pm 0.02$ & $0.09 \pm 0.02$ \\
\hline & Hippodamia glacialis & 0 & 0 & $0.003 \pm 0.003$ \\
\hline & Hippodamia parenthesis & $0.01 \pm 0.01$ & $0.01 \pm 0.01$ & $0.02 \pm 0.01$ \\
\hline & Hyperaspis binotata & 0 & $0.003 \pm 0.003$ & 0 \\
\hline & Hyperaspis undulata & 0 & $0.01 \pm 0.004$ & 0 \\
\hline & Psyllobora sp. & 0 & $.0003 \pm 0.003$ & $0.01 \pm 0.004$ \\
\hline \multirow[t]{3}{*}{ Diptera } & Dolichopodidae & $1.68 \pm 0.18$ & $5.52 \pm 0.49$ & $6.58 \pm 0.59$ \\
\hline & Empididae & $0.01 \pm 0.01$ & $0.03 \pm 0.01$ & $0.02 \pm 0.01$ \\
\hline & Syrphidae & $1.37 \pm 0.13$ & $1.75 \pm 0.11$ & $1.82 \pm 0.13$ \\
\hline Hemiptera & Nabidae & $0.06 \pm 0.02$ & $0.03 \pm 0.01$ & $0.08 \pm 0.02$ \\
\hline \multirow[t]{2}{*}{ Neuroptera } & Chrysopidae & $0.04 \pm 0.02$ & $0.04 \pm 0.01$ & $0.08 \pm 0.02$ \\
\hline & Hemerobiidae & $0.03 \pm 0.01$ & $0.03 \pm 0.01$ & $0.01 \pm 0.01$ \\
\hline
\end{tabular}

the switchgrass fields (Fig. 4a-f). In contrast, lady beetle species richness was negatively correlated with plant richness in switchgrass $\left(P=0.0386, r^{2}=0.43\right)$. In prairie sites, the intercept models exhibited the lowest $\mathrm{AIC}_{\mathrm{c}}$ values and were the best fit models predicting bee abundance, coccinellid species richness, coccinellid abundance, and exotic coccinellid abundance (Table 3). For coccinellid abundance, plant richness was a competing model for the intercept model. Bee species richness was best described by the best fitting bloom model in prairie sites (Table 3), and bee species richness was positively correlated with the mean number of flowering plant species found in prairie sites (Fig. 5a). The plant richness model was the best fit model predicting native coccinellid abundance, with the intercept model as a competing model. The abundance of native coccinellids was positively correlated with the diversity of plant species found in prairie sites (Fig. 5b).

\section{Discussion}

We compared multiple taxa of beneficial insects in three potential biofuel crops and found that many of these insect groups were either more abundant, species rich, or diverse in perennial and floristically diverse grasslands than in corn. These differences suggest that (1) the choice of biofuel crops could have profound impacts on the diversity of species that provide key ecosystem services, (2) that perennial, diverse biofuel crops are more likely to support more beneficial insects than annual crop monocultures, and (3) that field area and the management practices which influence floristic diversity are likely to be very important in supporting beneficial insects.

The three different biofuel crops we studied represent strikingly different plant communities. Corn is an annual row crop and generally has excellent weed control resulting in low abundance and diversity of flowering plants within fields. By the end of the season, most corn fields that we studied were over $2 \mathrm{~m}$ tall and had a completely closed canopy that covered extensive areas of bare ground. In contrast, both switchgrass and mixed prairie are perennial grasslands established using a drill with narrow row spacing or they are broadcast seeded. In either case, distinct rows were not visible and bare ground typically represented less than $5 \%$ of the area (B. Robertson unpublished data). Both switchgrass and mixed prairie had very heterogeneous canopy heights ranging from a few centimeters to more than $2 \mathrm{~m}$ tall. While we had initially predicted that switchgrass would have only moderate plant species 
Fig. 3 Mean number of (a) Coccinellidae, (b) Coccinellidae without C. maculata, (c) Dolichopodidae, (d) Syrphidae, and (e) Nabidae, collected weekly from yellow sticky card traps in corn, switchgrass, and prairie sites. A significant week $x$ treatment interaction was detected for Coccinellidae $(P<$ 0.0001), Dolichopodidae $(P<$ $0.0001)$, Syrphidae $(P<0.0009)$, and Nabidae $(P<0.0001)$. A marginally significant week $\times$ treatment interaction was detected for Coccinellidae without $C$. maculata $(P<0.0666)$. Letters indicate significant differences among treatments by week, measured using least squares means $(P<0.05)$. Unmarked weeks indicate no significant differences among the three treatments. Raw data are shown; analysis is based on $\log$ $(x+1)$-transformed data
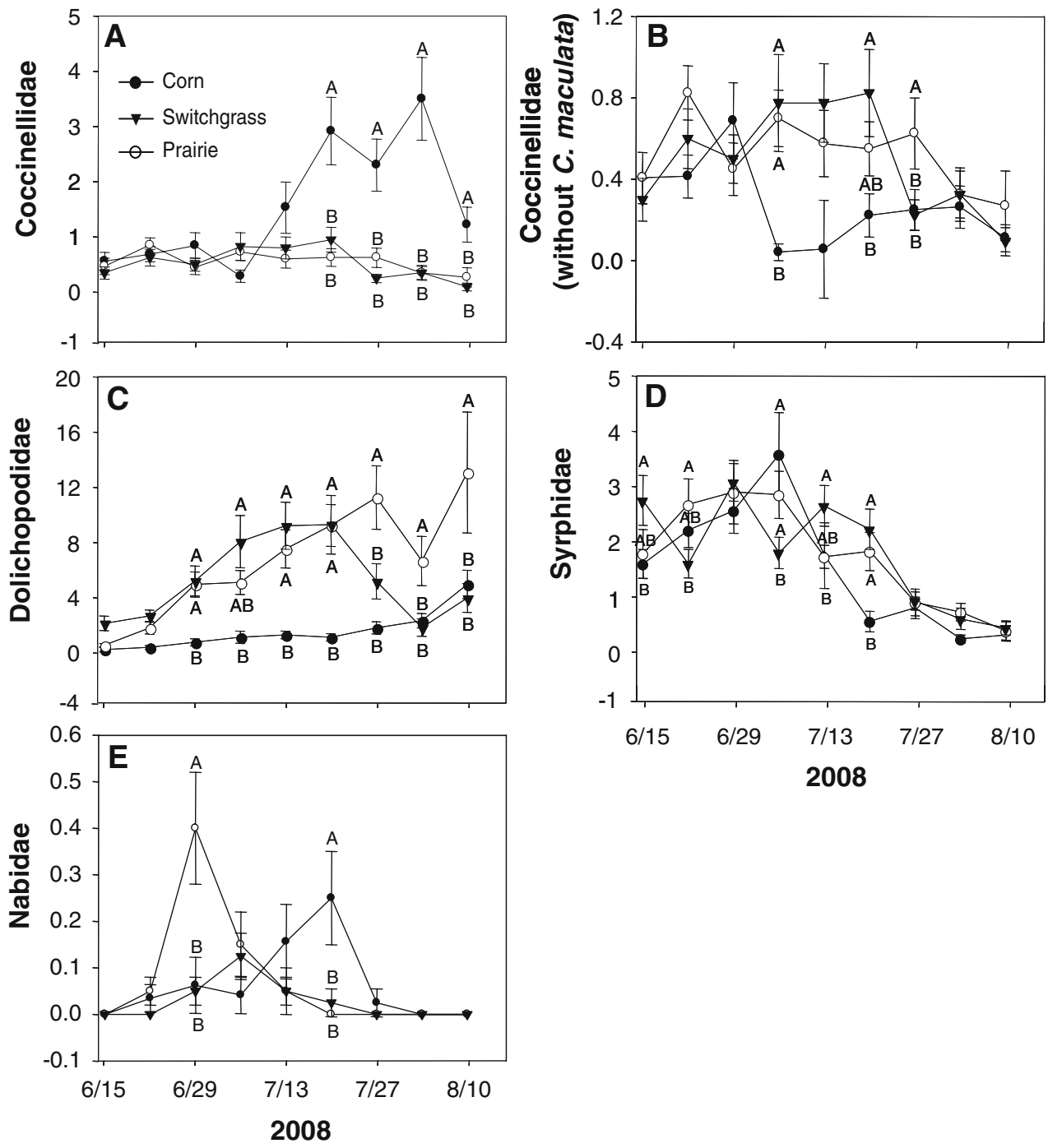

richness, we found that fields varied considerably from 13 to 38 plant species. This is very likely the result of the variable levels of management these fields are currently receiving. Most of our sites were planted as Conservation Reserve Program fields or were established specifically as wildlife habitat by the Michigan Department of Natural Resources or Pheasants Forever. When planted as a dedicated biofuel crop, switchgrass receives herbicide applications to promote single-species stands and modest annual fertilizer inputs to promote productivity [37]. Fields of switchgrass managed in this way typically have low plant species diversity, and the canopy is completely dominated by switchgrass (Landis personal observation). As such, we believe our switchgrass sites include fields that represent the upper levels of expected species richness for both plants and beneficial insects, and diversity is likely to be much reduced in switchgrass managed as a dedicated biofuel crop. Fields for this study were selected across southern Michigan, representing a range of climate, soil type, field size, and landscape contexts. While this provided a representative spectrum of field settings, it also introduced variability into our treatment groups. A truly controlled study using neutral sites planted to each biofuel crop was outside the scope of this study.

Pollinators This study is the first to compare native bee communities among biofuel crop types and provides an initial quantitative comparison of the bees present in three potentially important biofuel crops. Historically, agricultural regions of the Midwestern USA are known to have rich bee faunas, with the most complete records coming from the detailed studies of Robertson [33] and the follow-up study by Marlin and LaBerge [22]. These surveys recorded 214 and 154 species, respectively, but from more extensive sampling of different habitats and over a much greater time period. Identification of over 70 species in our study indicates that, despite this landscape currently being dominated by corn and soybean production, sufficient 
Table 3 Summary of model selection statistics for evaluating the abundance and species richness of bees and lady beetles in switchgrass and prairie sites

\begin{tabular}{|c|c|c|c|c|c|c|c|c|}
\hline Treatment & Variable & Model $^{\mathrm{a}, \mathrm{b}}$ & Log-likelihood & $K_{i}$ & $\mathrm{AIC}_{\mathrm{c}}$ & $\Delta_{i}$ & $W_{i}$ & Model $r^{2}$ \\
\hline Switchgrass & Bee species richness & $B_{0}+B_{1}$ area* & -1.95 & 3 & 13.86 & 0 & 0.85 & 0.56 \\
\hline Switchgrass & Bee abundance & $B_{0}+B_{1}$ area* & -7.39 & 3 & 24.74 & 0 & 0.67 & 0.43 \\
\hline Switchgrass & Coccinellidae species richness & $B_{0}+B_{1}$ area* & 1.99 & 3 & 5.98 & 0 & 0.54 & 0.49 \\
\hline Switchgrass & Coccinellidae species richness & $B_{0}+B_{1}$ (plant richness)* & 1.49 & 3 & 6.98 & 1.00 & 0.33 & 0.43 \\
\hline Switchgrass & Coccinellidae abundance & $B_{0}+B_{1}$ area** $^{*}$ & 4.62 & 3 & 0.72 & 0 & 0.91 & 0.66 \\
\hline Switchgrass & Native Coccinellidae abundance & $B_{0}+B_{1}$ area* & 6.16 & 3 & -2.36 & 0 & 0.64 & 0.42 \\
\hline Switchgrass & Exotic Coccinellidae abundance & $B_{0}+B_{1}$ area** & 8.39 & 3 & -6.82 & 0 & 0.98 & 0.71 \\
\hline Prairie & Bee species richness & $B_{0}+\mathrm{B}_{1}$ Bloom* & -3.30 & 3 & 16.56 & 0 & 0.91 & 0.61 \\
\hline Prairie & Bee abundance & $B_{0}$ & -11.53 & 2 & 28.78 & 0 & 0.54 & \\
\hline Prairie & Coccinellidae species richness & $B_{0}$ & 1.45 & 2 & 2.82 & 0 & 0.62 & \\
\hline Prairie & Coccinellidae abundance & $B_{0}$ & 5.19 & 2 & -4.66 & 0 & 0.58 & \\
\hline Prairie & Coccinellidae abundance & $B_{0}+B_{1}$ plant richness & 6.38 & 3 & -2.80 & 1.86 & 0.23 & 0.21 \\
\hline Prairie & Native Coccinellidae abundance & $B_{0}+B_{1}$ plant richness* & 8.03 & 3 & -6.10 & 0 & 0.62 & 0.44 \\
\hline Prairie & Native Coccinellidae abundance & $B_{0}$ & 5.10 & 2 & -4.48 & 1.62 & 0.28 & \\
\hline Prairie & Exotic Coccinellidae abundance & $B_{0}$ & 9.71 & 2 & -13.70 & 0 & 0.72 & \\
\hline
\end{tabular}

Four models were compared for each response variable: intercept only, area (field area in hectare), plant richness (mean number of plant species present per site), and bloom (mean number of plant species in bloom per site). Where two models are listed for the same variable, the first model listed is the minimum $\mathrm{AIC}_{\mathrm{c}}$ model. Only models with a $\Delta_{\mathrm{i}}$ of 2 or less are included as competing models

$B_{0}$ model intercept, $B_{1}$ model slope, $K_{i}$ number of estimable parameters in model, $A I C_{c}$ Akaike's Information Criterion adjusted for a small sample size, $\Delta_{i}$ AIC difference (difference in $\mathrm{AIC}_{\mathrm{c}}$ score between the lowest $\mathrm{AIC}_{\mathrm{c}}$ model and other candidate models), $W_{i}$ Akaike weight (the weight of evidence in favor of a given model compared with the other models considered)

$* P<0.05 ; * * P<0.01$

${ }^{\mathrm{a}} B_{o}=$ intercept only models

${ }^{\mathrm{b}}$ Variables in parentheses indicates a negative correlation

nesting and food resources remain to support a variety of bee species. We expected corn to have an impoverished bee community compared with the other two biofuel types, but species richness was found to be similar across treatments, indicating that other factors such as landscape context [32] or field management intensity [18] are also shaping the bee communities in these fields. Bee diversity and abundance have been linked previously to the floral resources present in landscapes [16, 28, 43, 51], and our finding of more abundant bee communities in prairie and switchgrass sites compared with corn supports some of these earlier findings. In addition, our study demonstrates that the scale of production (field size) also influences bee communities with larger switchgrass fields having greater bee abundance and species richness.

The high abundance of Ceratina spp., Agapostemon spp., and various Lasioglossum spp. in these Midwestern biofuel landscapes indicates that, as with most bee communities, stem and soil-nesting sites will be important for maintaining diverse bee communities [29, 46]. Ceratina are small stem-nesting bees that may find suitable pithy grass and forb stems for nesting in the switchgrass and prairie sites. Indeed, only one Ceratina was trapped in the corn sites compared with over 200 in both of the other biofuel types, and similar bias towards non-corn biofuels was found for some Osmia spp., Hoplitis spp., and for Hylaeus affinis/modestus that nest in stems. Similar patterns were seen for halictid bees, most of which are groundnesting species. The lack of annual soil tillage and the relative accessibility of potential nesting sites in prairie and switchgrass fields are expected to be important factors allowing these species to thrive whereas they were relatively scarce in corn.

Captures of bees in the bowl traps in June were higher in prairie and switchgrass sites than in corn. This pattern continued in July, although the number of bees trapped declined later in the season. The decline in captures through the season may be caused by the location of the bowl traps on the ground such that they are increasingly obscured as the plant canopies develop. This may prove to be a general problem with deploying the standard bowl trapping method for monitoring bees [10] in studies comparing crops with varying architecture and growth habits. Tuell and Isaacs [46] found higher captures of bees in bowl traps when they were raised to the height of the flowers being visited by bees, and further research is underway to determine the 
Fig. 4 Relationship between (a) bee abundance and field area (variable area) in switchgrass, (b) bee species richness (Simpson's D) and field area (variable area) in switchgrass, (c) Coccinellidae abudance and field area (variable area) in switchgrass, (d) Coccinellidae species richness (Simpson's D) and field area (variable area) in switchgrass, (e) native cocinellid abundance and field area (variable area) in switchgrass, and (f) exotic coccinellid abundance and field area (variable area) in switchgrass
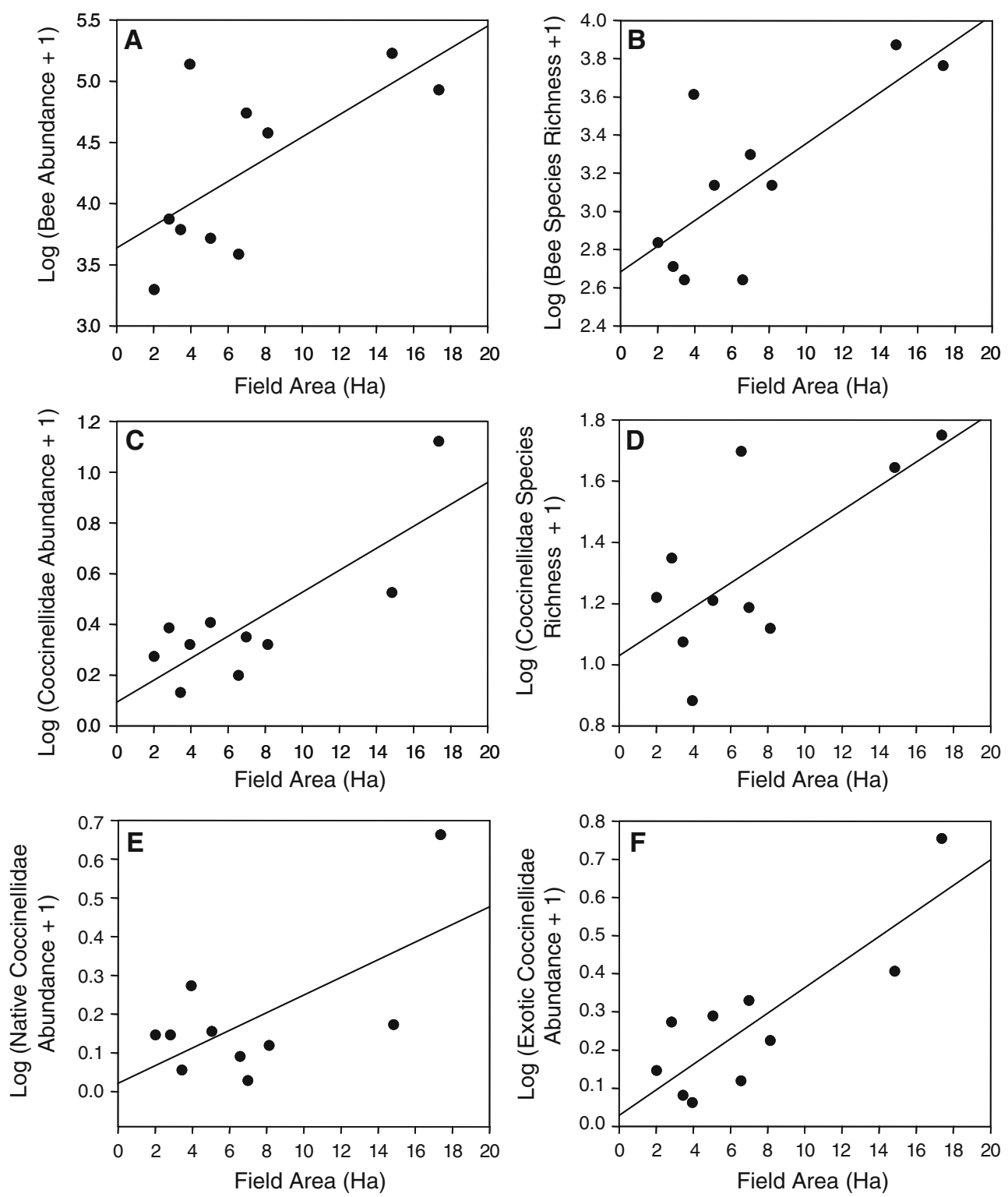

Fig. 5 Relationship between (a) bee species richness (Simpson's D) and the mean number of plant species in bloom (variable bloom) in prairie, (b) native coccinellid abedaunce and mean number of plant species present (variable plant richness) in prairie
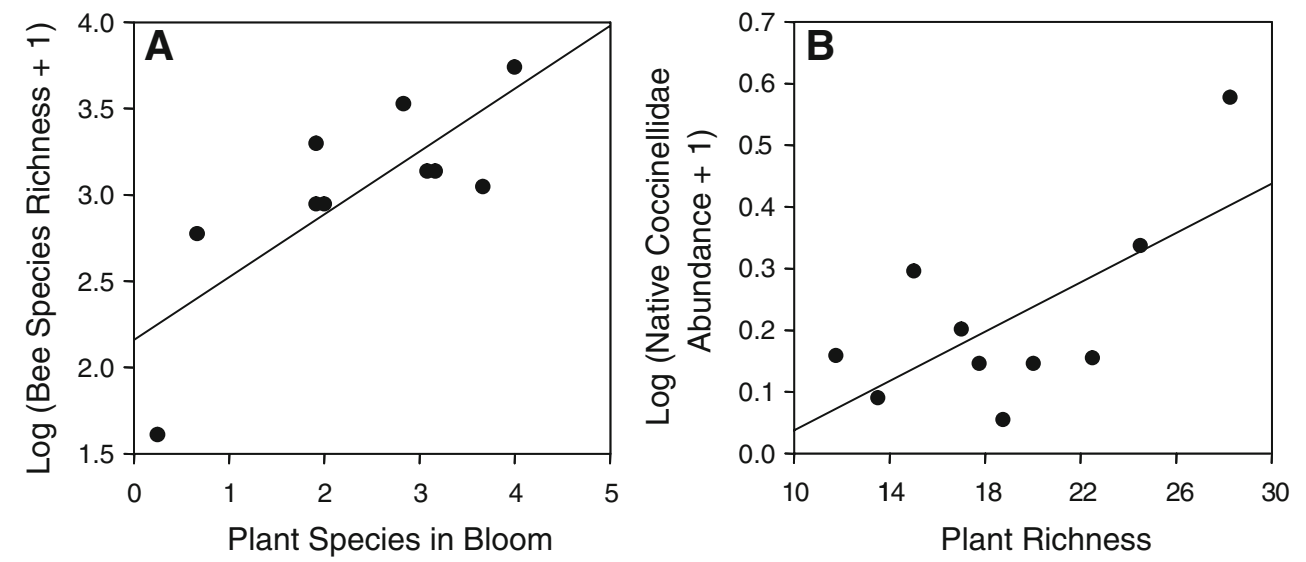
optimal placement of bowl traps for monitoring bees in these biofuel crops.

Predators The biodiversity profiles of the potential biofuel crops differed significantly for several of the predatory insect taxa sampled. Overall lady beetle abundance was highly influenced by the relative abundance of $C$. maculata in corn compared with switchgrass and mixed prairie. As a pollen feeder [6], C. maculata is well known to be highly abundant in corn, especially during anthesis where it can be an important predator on European corn borer (Ostrinia nubilalis) eggs [26]. Without C. maculata, corn in our study tended to have the lowest abundance of Coccinellidae. In contrast, both switchgrass and mixed prairie maintained relatively constant abundance of coccinellids throughout much of the season and had higher species richness compared with corn sites. Prior work has shown that several common Midwestern prairie plants harbor low but persistent populations of aphid prey including Aphis monardae on wild bergamot Monarda fistulosa L. (Lamiaceae), Aphis oestlundi on evening primrose, Oenothera biennis L. (Onagraceae), and Aphis asclepiadis on common milkweed Asclepias syriaca L. (Apocynaceae) [52]. Such prey may represent a relatively consistent resource for coccinellids and other aphidophagous species. Several relatively rare native coccinellid species were found in switchgrass and prairie sites. The coccinellid B. ursina was the second and third most abundant species found in prairie and switchgrass sites, respectively. This species has been reported to have declined following the introduction of the multicolored Asian lady beetle, Harmonia axyridis, in Michigan [4]. Other uncommon species included $H$. glacialis, H. binotata, H. undulata, and Psyllobora sp.

Lady beetle diversity $(D)$ and the abundance of both native and exotic species were positively correlated with switchgrass field size, illustrating that a larger, more diverse coccinellid community is supported by larger grasslands (switchgrass fields sampled ranged in size from 2.0 to 17.4 ha). Interestingly, we found that switchgrass fields with lower within-field plant diversity supported a higher diversity of coccinellids. In prairie sites, there was not a significant correlation between within-field plant diversity and coccinellid diversity; however, we did find that the abundance of native coccinellids increased with plant diversity. These differences may be due to the specific plants found in the prairie and switchgrass sites and the resources that they may or may not provide to predators. At the landscape scale, Gardiner et al. [13] found that grassland area was positively correlated with the abundance of native coccinellids in soybean fields. The addition of weedy switchgrass or prairie as bioenergy crops to landscapes where supporting resources are lacking may benefit both predator community diversity and abundance and the biocontrol services they supply at the landscape scale.

Other predatory groups showed varying responses to biofuel crops. Dolichopodidae were the most abundant predatory insects in our study and were frequently more abundant in prairie and switchgrass. While Dolichopodidae are generally considered minor predators in annual crops, they are known to be attracted to resource strips in agricultural habitats [14] and are commonly collected in surveys of insect fauna in crop fields. In noncrop habitats, they feed on black flies, mosquitoes, and several bark beetle species [2, 7, 9, 49]; however, their function within croplands is currently not well understood. Syrphidae and Nabidae were not strikingly more abundant in one crop over another, although there were significant differences among crops on a few specific sampling days. Overall, syrphid abundance was highest in the spring, while nabids were generally found in low abundance throughout the season.

\section{Conclusions}

This study is the first to assess the implications of different biofuel crops for beneficial insects that provide valuable ecosystem services in agricultural landscapes. Overall, it suggests that there are important consequences for these organisms in the type of biofuel crop that is grown. Our results indicate that, as an annual crop with low plant diversity and high levels of soil disturbance, corn tends to have low abundance and diversity of these beneficial insects. In contrast, both perennial grassland-based biofuel crops examined here harbored higher abundance, species richness, and diversity of beneficial arthropods compared with corn monocultures. Additional research will determine whether such differences result in increased pollination or pest suppression services in these landscapes. Further studies should also explore whether biofuel crops may also harbor pest insects that cause crop damage or vector crop diseases. Our analysis suggests that both within-field plant diversity and field area are likely to influence these patterns. As such, further examination of local- and landscape-level drivers of bee and natural enemy populations in agricultural landscapes that include biofuel crops may help elucidate how best to combine the goals of biofuel production and conservation of beneficial insects. For example, it appears that the addition of perennial grassland biofuel crops such as switchgrass and mixed prairie to annual crop-dominated agricultural landscapes can help support beneficial arthropods and the services they provide. 
Finally, our findings suggest important policy implications. US government policy towards cellulosic biofuels is currently driven by stated targets for ethanol production. As such, much research is focused on attaining high biomass productivity and corresponding efficiency in processing, without explicit consideration of the landscape-level environmental impacts such systems may induce. Our results suggest that the type of biofuel crops produced and the landscape patterns that result will have impacts on key arthropod-mediated ecosystem services such as pollination and pest suppression. Inclusion of perennial biofuel crops in agricultural landscapes may increase landscape diversity with positive impacts on a variety of ecosystem services. Future bioenergy policy should be developed to explicitly enhance biodiversity as a means of improving the delivery of ecosystem services by agricultural landscapes, while also meeting biofuel production targets.

Acknowledgements We thank Lauren Bailey, Nick Longbucco, Denae Baker, Michael Bigsby, Laura Mace, Becky McCormack, Katy Bigsby, Scott Prajzner, Courtney Hendon, and Grace O'Connor for their assistance with the fieldwork. Thanks also to Kay Gross, Carol Baker, and Pam Moseley for assistance with plant sampling and identification and Bruce Robertson for plant structural data. Ben Werling and three anonymous reviewers provided valuable comments on an earlier draft. This work was funded in part by the Department of Energy Great Lakes Bioenergy Research Center (DOE Office of Science BER DE-FC02-07ER64494), the USDA-NRI Program (Award 2007-3530218272), and the Michigan Agricultural Experiment Station.

\section{References}

1. Andow DA (1991) Vegetational diversity and arthropod population response. Annu Rev Entomol 36:561-586

2. Aukema BH, Raffa KF (2004) Behavior of adult and larval Platysoma cylindrica (Coleoptera: Histeridae) and larval Medetera bistriata (Diptera: Dolichopodidae) during subcortical predation of Ips pini (Coleoptera: Scolytidae). J Insect Behav $17: 115-128$

3. Bellamy PE, Croxton PJ, Heard MS, Hinsley SA, Hulmes L, Hulmes S et al (2009) The impact of growing Miscanthus for biomass on farmland bird populations. Biomass \& Bioenergy 33:191-199

4. Colunga-Garcia M, Gage SH (1998) Arrival, establishment, and habitat use of the multicolored Asian lady beetle (Coleoptera: Coccinellidae) in a Michigan landscape. Environ Entomol 27:1574-1580

5. Cook JH, Beyea J, Keeler KH (1991) Potential impacts of biomass production in the United States on biological diversity. Ann Rev Energy Environ 16:401-431

6. Cottrell TE, Yeargan KV (1998) Effect of pollen on Coleomegilla maculata (Coleoptera: Coccinellidae) population density, predation, and cannibalism in sweet corn. Environ Entomol 27:14021410

7. Coulibaly B (1993) Dolichopodidae (Diptera) in biologicalcontrol of certain insect pests of forest ecosystems. Insect Sci App 14:85-87

8. Daily GC (1997) Nature's services: societal dependence on natural ecosystems. Island Press, Washington, 392pp
9. Dippel C, Heidger C, Nicolai V, Simon M (1997) The influence of four different predators on bark beetles in European forest ecosystems (Coleoptera: Scolytidae). Entomol Gen 21:161-175

10. Droege S (2009) The very handy bee manual: how to catch and identify bees and manage a collection. http://www.nbii.gov/ images/uploaded/152986_1244054830561_Handy_Bee_Manual_ Jun 2009.pdf.

11. Fiē̄ler AK, Landis DA, Wratten SD (2008) Maximizing ecosystem services from conservation biological control: the role of habitat management. Biol Control 45:254-271

12. Gardiner MM, Landis DA, Gratton C, DiFonzo CD, O’Neal M, Chacon JM et al (2009) Landscape diversity enhances biological control of an introduced crop pest in the north-central USA. Ecol Appl 19:143-154

13. Gardiner MM, Landis DA, Gratton C, Schmidt NP, O'Neal M, Mueller ED et al (2009) Landscape composition influences patterns of native and exotic ladybeetle abundance. Divers Distrib 15:554-564

14. Hausammann A (1996) The effects of weed strip-management on pests and beneficial arthropods in winter wheat fields. Z Pflanzenkr Pflanzenschutz 103:70-81

15. Hill J, Nelson E, Tilman D, Polasky S, Tiffany D (2006) Environmental, economic, and energetic costs and benefits of biodiesel and ethanol biofuels. PNAS 103:11206-11210

16. Hines HM, Hendrix SD (2005) Bumble bee (Hymenoptera: Apidae) diversity and abundance in tallgrass prairie patches: effects of local and landscape floral resources. Environ Entomol 34:1477-1484

17. Isaacs R, Tuell J, Fiedler A, Gardiner M, Landis D (2009) Maximizing arthropod-mediated ecosystem services in agricultural landscapes: the role of native plants. Front Ecol Environ 7:196-203

18. Kremen C, Williams NM, Thorp RW (2002) Crop pollination from native bees at risk from agricultural intensification. PNAS 99:16812-16816

19. Landis DA, Gardiner MM, van der Werf W, Swinton SM (2008) Increasing corn for biofuel production reduces biocontrol services in agricultural landscapes. PNAS 105:20552-20557

20. Landis, DA, Werling BP (2010) Arthropods and biofuel production systems in North America. Insect Sci (in press)

21. Losey JE, Vaughan M (2006) The economic value of ecological services provided by insects. Bioscience 56:311-323

22. Marlin JC, LaBerge WE (2001) The native bee fauna of Carlinville, Illinois, revisited after 75 years: a case for persistence. Conservation Ecology 5: 9. www.consecol.org/vol5/iss1/art9/

23. McLaughlin SB, Kszos LA (2005) Development of switchgrass (Panicum virgatum) as a bioenergy feedstock in the United States. Biomass \& Bioenergy 28:515-535

24. Naylor RL, Liska AJ, Burke MB, Falcon WP, Gaskell JC, Rozelle SD et al (2007) The ripple effect: biofuels, food security, and the environment. Environment 49:30-43

25. Parrish DJ, Fike JH (2005) The biology and agronomy of switchgrass for biofuels. Crit Rev Plant Sci 24:423-459

26. Phoofolo MW, Obrycki JJ (1998) Potential for intraguild predation and competition among predatory Coccinellidae and Chrysopidae. Entomol Exp Appl 89:47-55

27. Pimental D, Pimental DH (2007) Food, energy and society. CRC Press, Boca Raton, p 380

28. Potts SG, Vulliamy B, Dafni A, Ne'eman G, Willmer P (2003) Linking bees and flowers: how do floral communities structure pollinator communities? Ecology 84:2628-2642

29. Potts SG, Vulliamy B, Roberts S, O'Toole C, Dafni A, NE'Eman G et al (2005) Role of nesting resources in organizing diverse bee communities in a Mediterranean landscape. Ecol Entomol 30:78-85

30. Rehan SM, Richards MH (2008) Morphological and DNA sequence delineation of two problematic species of Ceratina 
(Hymenoptera: Apidae) from eastern Canada. J Ent Soc Ont 139:59-67

31. R Development Core Team (2005) R: a language and environment for statistical computing. R Foundation for Statistical Computing, Vienna

32. Ricketts TH, Regetz J, Steffan-Dewenter I, Cunningham SA, Kremen C, Bogdanski A et al (2008) Landscape effects on crop pollination services: are there general patterns? Ecol Lett 11:499-515

33. Robertson C (1929) Flowers and insects. Lists of visitors to four hundred and fifty-three flowers. Science Press, Lancaster

34. Robertson GP, Dale VH, Doering OC, Hamburg SP, Melillo JM, Wander MM et al (2008) Sustainable biofuels redux. Science 322:49-50

35. Russelle MP, Morey RV, Baker JM, Porter PM, Jung HJG (2007) Comment on "Carbon-negative biofuels from low-input highdiversity grassland biomass". Science 316:1567b

36. Institute SAS (1999) SAS/stat users guide first edition, vol 1. SAS Institute, Cary

37. Schmer MR, Vogel KP, Mitchell RB, Perrin RK (2008) Net energy of cellulosic ethanol from switchgrass. PNAS 105:464-469

38. Schubert C (2006) Can biofuels finally take center stage? Nat Biotechnol 24:777-784

39. Searchinger T, Heimlich R, Houghton RA, Dong FX, Elobeid A, Fabiosa J et al (2008) Use of US croplands for biofuels increases greenhouse gases through emissions from land-use change. Science 319:1238-1240

40. Semere T, Slater FM (2007) Invertebrate populations in miscanthus (Miscanthus $x$ giganteus) and reed canary-grass (Phalaris arundinacea) fields. Biomass \& Bioenergy 31:30-39

41. Shmida A (1984) Whittaker plant diversity sampling method. Isr J Bot 33:41-46

42. Simpson EH (1949) Measurement of diversity. Nature 163:688688
43. Tepedino VJ, Stanton NL (1981) Diversity and competition in bee-plant communities on short-grass prairie. Oikos 36:35-44

44. Tilman D, Hill J, Lehman C (2006) Carbon-negative biofuels from low-input high-diversity grassland biomass. Science 314:1598-1600

45. Tilman D, Socolow R, Foley JA, Hill J, Larson E, Lynd L et al (2009) Beneficial biofuels - the food, energy, and environment trilemma. Science 325:270-271

46. Tuell JK, Isaacs R (2009) Elevated pan traps to monitor bees in flowering crop canopies. Entomol Exp Appl 131:93-98

47. Tyner WE (2008) The US ethanol and biofuels boom: its origins, current status, and future prospects. Bioscience 58:646-653

48. Ward KE, Ward RN (2001) Diversity and abundance of carabid beetles in short-rotation plantings of sweetgum, maize and switchgrass in Alabama. Agroforest Syst 53:261-267

49. Werner D, Pont AC (2003) Dipteran predators of simuliid blackflies: a worldwide review. Med Vet Entomol 17:115-132

50. Westcott PC (2007) Ethanol expansion in the United States: how will the agricultural sector adjust? Department of Agriculture Economic Research Service, Washington D.C

51. Williams NM, Kremen C (2007) Resource distributions among habitats determine solitary bee offspring production in a mosaic landscape. Ecol Appl 17:910-921

52. Wyckhuys KAG, Koch RL, Kula RR, Heimpel GE (2009) Potential exposure of a classical biological control agent of the soybean aphid, Aphis glycines, on non-target aphids in North America. Biol Invasions 11:857-871

53. Ribic CA, Sample DA (2001) Associations of grassland birds with landscape factors in southern Wisconsin. Amer Midland Nat 146:105-121

54. Burnham KP, Anderson DR (2002) Model selection and multimodel inference: A practical information-theoretic approach. 2nd ed, Springer-Verlag, New York 